\title{
Monopsony, powerful buyers and small sellers: analysis of Malaysian competition law and lessons learnt from Indonesia
}

\section{Haniff Ahamat*}

Faculty of Law,

National University of Malaysia (UKM),

43600, UKM Bangi, Selangor, Malaysia

Email: haniff@ukm.edu.my

*Corresponding author

\section{Nasarudin Abdul Rahman}

Ahmad Ibrahim Kulliyyah of Laws, International Islamic University Malaysia (IIUM), P.O. Box 10, 50728, Kuala Lumpur, Malaysia Email: nasarudin@iium.edu.my

\section{Milyan Risydan Al Anshori}

Faculty of Law, Universitas 17 Agustus 1945 Semarang (UNTAG Semarang), Jl. Pawiyatan Luhur, Bendan Dhuwur, Semarang, 50233, Indonesia Email: milyansay@gmail.com

\begin{abstract}
Powerful buyers have become a problem stifling the market presence of micro, small and medium businesses. Their power in both upstream and downstream markets may allow them to manipulate prices or output. The authors look at whether competition law can address such problem particularly in Malaysia. They use monopsony as the theoretical framework and find that the Malaysian Competition Act 2010 can only be used indirectly against the conduct of powerful buyers due to the lack of express reference to the term monopsony. The existing rules are more often operationalised on the supply side rather than the demand side, making proving the anti-competitive conduct of those buyers difficult. In Indonesia, the main competition legislation i.e. the Law No. 5 of 1999 can be directly used but proving legal violation is also difficult. However, Indonesia has a specific law that protects small sellers from powerful buyers' use of their market power.
\end{abstract}

Keywords: competition law; competition policy; socio-economics of market regulation; promotion of small business; law and supply chain management; Indonesia.

Reference to this paper should be made as follows: Ahamat, H., Rahman, N.A. and Al Anshori, M.R. (2020) 'Monopsony, powerful buyers and small sellers: analysis of Malaysian competition law and lessons learnt from Indonesia', Int. J. Globalisation and Small Business, Vol. 11, No. 3, pp.241-257. 
Biographical notes: Haniff Ahamat is an Associate Professor at the Faculty of Law, the National University of Malaysia (UKM). He holds an LLB (Hons.) from IIUM, an LLM from UKM and a PhD from University of Essex, UK. He wrote his $\mathrm{PhD}$ thesis on the consumer perspectives of Malaysian and EC anti-dumping regimes. He is a non-practising member of the Malaysian Bar. $\mathrm{He}$ has researched and published on public international law, law of WTO, competition law and law of economic regulation.

Nasarudin Abdul Rahman is an Assistant Professor at the Ahmad Ibrahim Kulliyyah of Laws, International Islamic University Malaysia (IIUM). He obtained his LLB (Hons) from IIUM, his Master in Comparative Laws (MCL) also from IIUM and his PhD from Macquarie University, Australia in the area of competition policy and law in Malaysia. He is the author of a book entitled 'Competition Law in Malaysia' published by Thomson Reuters and had published many articles relating to competition law and policy in Malaysia. Currently, he is a member of the Malaysia Competition Commission.

Milyan Risydan Al Anshori is a Doctoral candidate from University of 17 August 1945 Semarang. He joined Indonesia Customs Service since he was 19 years old after finishing his diploma majoring in Customs and Excise Study. He has been in service for 13 years. He holds a Diploma degree in Customs and Excise Study from Indonesia National Customs Academy, Bachelor of Laws from University of Bung Karno, and Master of Laws from University of 17 August 1945 Semarang.

\section{Introduction}

Powerful buyers have become a problem stifling the market presence of micro, small and medium businesses in many countries including Malaysia. They may refer to middlemen who buy commodities from farmers and fishermen as gatherers, mere buyers, brokers, traders, marketers or even creditors. They may also refer to consumers of raw materials who manufacture them into finished products before being sold to end users.

The Malaysian Government has been critical of these powerful buyers especially in sectors with high level of participation of traditional market players. The Malaysian Government (through its Ministry of Agriculture) launched a 'crusade' against middlemen in 2014 to free poor fishermen from being subjugated by powerful buyers (Utusan Malaysia, 2014). The same sentiment has been echoed in Malaysia's neighbour, Indonesia. In Indonesia, middlemen had been cited as one of the causes of farmers' poverty (Rakyat Pos, 2015) and calls to combat powerful buyers in the agricultural sector had been made by many elements within the government including the military (Antaranews, 2017).

The presence of powerful buyers may not necessarily harm farmers and consumers in general. Cooperation between them may reduce negative externalities and the cost of state interference. This can be seen in the palm oil sector in Malaysia (Ishak et al., 2017). However, more often than not, powerful buyers imposed very low price on farmers or fishermen but resold the produce at far too high price reaping supra-competitive profits. This harms both the farmers and end users. Some powerful buyers also gave credit to farmers or fishermen who struggle to pay off their debts and this has cultivated a culture of dependency on the powerful buyers. 
Since powerful buyers have the tendency to use their market position to exploit the farmers or fishermen, it is important to look at whether competition law can address the powerful buyers issue in the context of a small seller. Small seller here refers to a seller who is a micro enterprise or very small enterprise. Smaller business players are categorised into micro, small and medium enterprises (SMEs). The categorisation is based on number of employees and volume of sales of a business, which may differ from one country and another. In Malaysia, a business whose annual sales are lower than USD72,000 or has fewer than five employees, is a microenterprise (SME Corp Malaysia, 2013). However, a small enterprise can have annual sales up to USD3.6 million or employees of up to 75 (SME Corp Malaysia, 2013). This disparity is away from the scope of this paper, but it explains the terminological flexibility employed by this with regards to micro seller and/or small seller. This paper chooses small seller for easier comprehension by readers.

Competition law has specific principles on the concept of buyer power. Normally, it is the seller who has power in the market. However, in many circumstances, the power is also held by the buyer who is the powerful buyer or manufacturer of a finished product. Other than buyer power, there is also the concept of monopsony. The difference between them is the number of the buyer. Monopsony happens when there is only one buyer. Despite competition law recognising the concept of monopsony or buyer power, its implementation is still limited as shown by experiences in many countries including Malaysia. In Indonesia although the competition law is more advanced and has clearer rules on monopsony, the application of those rules against monopsonist and powerful buyers still have some constraints.

This paper will discuss the scenario of monopsony in Malaysia and to what extent the issue of monopsony or misuse of power by powerful buyer in a market can be addressed through the lens of competition law. This paper will be divided into the following sections. First, it will discuss the concept monopsony and how it relates to the issue powerful buyers. Second, it will explore the monopsony scenarios in Malaysia. This will be followed by a discussion on the relevant Malaysian competition legal framework as well as its deficiencies, followed by the lessons that can be learnt from a selected jurisdiction that is Indonesia.

\section{Monopsony in the context of powerful buyers vs. small sellers}

Before looking into the literature gaps underlying the theme of this paper, it is important to understand the different types of market in terms of competition. This is because the nature of this paper concerns regulation of competition in the market. The first type of market is perfect competition. When competition in the market is perfect, there are many buyers and many sellers for a homogenous product and within the same geographic area. Price will be near the marginal cost of the producer or seller of the product concerned hence consumers will benefit in terms of both price and output. The second type of market is imperfect competition. Imperfect competition happens when there is only one seller and many buyers for a homogenous product and within the same geographic market. In this situation, price is dictated by the monopolist who can earn monopoly profits even without producing output at the optimum level. The producer will enjoy 
surplus which cannot compensate losses suffered by consumers in terms of high prices or limited output.

The explanation on imperfect competition revolves around market power on the supply side, whereas the concerns in the plight of small sellers against the use of buyer power regards market power on the demand side. This is where monopsony comes into the picture. Monopsony is the market power on the demand side of the market and a monopsonist "is characterized by the only or dominant buyer in town" [Stucke, (2013), p.1510] where a single (or dominant) buyer deals with multiple sellers [OECD, (2008), 245].

There are writings that look at the effects of monopsony or buyer power, and the findings are mixed that is the effect of monopsony or buyer power can be both positive and negative. If buyer power results in lower prices for the consumers of finished products produced from inputs sold by a monopsonist buyer, there can be a good reason for monopsony to be tolerated [OECD, (2008), p.257]. However, the existence of a monopsonist buyer can negatively impact the buyer's competitors. If the monopsonist buyer imposes a single price to different sellers, the monopsonist buyer can buy up inputs from efficient sources but this will leave its competitors with less efficient sources for their inputs (Noll, 2004). The monopsonist buyer can harm the input market. If the supply curve in the input market is inelastic, it will be costly to convert investment in facilities and factors of production for the inputs for other uses [Stucke, (2013), pp.1536-1537] especially when the monopsonist buyer is protected by entry barriers [Noll, (2004), p.602]. This will discourage such investment and in the long run can reduce future supply of inputs (Noll, 2004). Suppliers of input will compare the costs of producing supply with the expected gains and this will reduce competition within the input market as it becomes less attractive to enter such market, reducing the quality of the products or services that form part of the inputs [Noll, (2004), pp.605-606].

These writings show how important for competition law to address buyer power. In fact, it is possible that monopsony can be more dangerous than monopoly. It has been argued that monopsony is more dangerous when it comes to mergers (Carstensen, 2004). On the other hand, monopoly is more lethal than monopsony with regards to collusion (Jacobson and Dorman, 1992). Joint purchasing or purchasing cooperatives can have pro-competitive effects because they could centralise ordering, combine warehousing or distribution functions or achieve other efficiencies [Federal Trade Commission and US Department of Justice, (2000), para. 3.31(a); OECD, (2008), p.248]. Despite the views that suggest a lesser evil of collusion by buyers, powerful buyers can form buyer cartels and if the cartels are implemented against poor farmers while the buyers also control the downstream market, the effect can be devastating. Similarly, mergers by buyers can be relatively more dangerous but development of law on mergers in countries like Malaysia is slower than on antitrust (anti-competitive agreement and abuse of dominance).

There is another issue that is the writings that theorise monopsony or buyer power do not view such power in the more specific context of the relationship between small sellers and powerful buyers which is evident in sectors such as agriculture. There are writings that discuss the market character of middlemen and whether these buyers harm sellers or farmers. The study by Enete (2009) shows that in the cassava market in Africa, middlemen did not engage in monopsony purchases because farmers sold higher volume of cassava products in the market than powerful buyers while prices appeared more stable 
in countries with more elaborate involvement of powerful buyers. Hayami et al. (1988) also reveal the same pattern in the soybean market in Indonesia where middlemen did not exercise monopsony power and the soybean farmers preferred to deal with powerful buyers because of the lower transportation cost than if they trade directly with retailers. Improvements in transportation infrastructure is a relevant factor that explains the preceding scenarios because in reducing the transportation cost, farmers would start to explore alternative market and this may disadvantage traders including middlemen [Suzuki and Sexton, (2005), p.13]. Surprisingly, the writings that discuss the practice of middlemen point to a disconnect between the middlemen and monopsony/buyer power. It is inappropriate to over-generalise things. A more recent study by Mitra et al. (2018) for example, shows that powerful marketing buyer in the potato market in West Bengal, India earned large margins on average and such margins reflected barriers to entry against farmers' access to the market as the prices in the market were not passed through to consumers.

Thus, the literature should link the theories attacking or justifying monoposony and buyer power, to the legal consequences of powerful buyer's conduct against small sellers. Such literature should highlight important elements associated with monopsony such as coercion. "The more the evidence shows that the defendant is forcing sellers to do things that they would not otherwise do in a competitive market, the more likely the defendant is a monopsonist, even when the defendant's market is relatively low" [Stucke, (2013), pp.1539-1540]. A monopsonist can use its buyer power to force smaller sellers to sell their product to the monopsonist below competitive levels. In order to meet the selling target, rather than stopping production, the sellers particularly farmers will continue producing. This can push prices of commodities further down. At the downstream level however, the monopsonist can keep prices high for the ultimate consumers if they have monopoly power over the output market. In many ways buyer power can give rise to human right issues [Stucke, (2013), pp.1509-1510; Ganesh, (2010), p.1190].

However, the literature does not give an answer to the extent to which competition law can adequately address these elements particularly in developing economies like Malaysia. There is rich literature that debates whether competition law should respond to non-efficiency, socio-economic or developmental concerns. However, there is a need to steer away from such teleological approach and move towards the bread and butter of competition legislative provisions, which will be undertaken in this paper. This is because monopsony or buyer power really affects small sellers particularly in the agricultural sector, and there is a need for competition law to play its role.

\section{Monopsony scenario in Malaysia involving powerful buyers and small sellers}

The discussion on the monopsony scenarios in Malaysia that involve powerful buyers and small sellers will justify the role of competition law in remedying the problems faced by such sellers. Just as in other developing countries, such monopsony scenarios in Malaysia are evident in the agricultural sector. Dealers in crops, fish and other agricultural products who buy from small holding farmers or fishermen have been touted as engaging in monopsonist and powerful buyers. The powerful buyers are believed to be exploiters of poor farmers (Landa, 2016). Stories about these dealers are not necessarily negative. 
These dealers can act as buffers for the farmers during hard times such as natural disaster or unfavourable market conditions (Ray, 1994). Powerful buyers are also not confined to private parties. In certain sectors such as rice, the role of such powerful buyers has been played by state-appointed company. This paper chooses two sectors to be analysed:

1 rice

2 poultry.

\subsection{Rice}

The rice sector is very important to a country like Malaysia as the staple food of the majority of its population is rice. Hence rice is a sensitive issue that has a bearing on food security. Rice is also a sensitive product because the rice sector 'employs' thousands of poor farmers who live in most of the disadvantaged regions in Malaysia.

The main player is Padiberas Nasional Berhad (BERNAS) which is a privately-owned state trading enterprise. To say BERNAS is not totally performing government functions is not accurate because it came into existence as a result of the corporatisation of the National Paddy and Rice Board (LPN). In relating BERNAS to the supply chain of rice in Malaysia, the company is the sole importer rice at duty free rates (Vengedasalam et al., 2011). The imported rice will go to first, the national stockpile and second, to BERNAS trading stocks, which means they will be sold to wholesalers (some wholesalers are owned by BERNAS) (Vengedasalam et al., 2011). As regards the locally produced rice, local farmers will sell paddy at a price set by the government to millers some of whom are owned by BERNAS (Vengedasalam et al., 2011). The millers will sell processed rice to wholesalers, just as the case of imported rice, before the product reaches retailers. BERNAS also has a say in grading the yields produced by paddy farmers (ChePa et al., 2016) and acts as a medium for channelling subsidies to farmers (Yong, 2008).

While BERNAS received monopolistic concession from government to import rice [even so, the new Pakatan Harapan Government has committed in 2018 to distribute a portion of the imports (i.e., 30\%) to other importers (Rashid, 2018)], it is not clear whether it monopolises paddy purchasers from farmers. Vengedasalam et al. show that BERNAS-owned millers has only around 30\% market share. Thus, there is still considerable competition at the downstream market. Furthermore, the price at that market is controlled by the government for the sake of price stability. As such its dealings in the market ideally have to reflect certain minimum protection for farmers and consumers. It has to offer the guaranteed minimum prices (GMP) to farmers while at the same time striving to make the price of rice when it reaches end users reflect the world market price (Vengedasalam et al., 2011).

The market features including the supply chain are more complicated than most of us thought. As put by Wong et al. (2010) competition in the rice sector in Malaysia occurs between groups of companies tied formally or informally with one another. These groups of companies form strategic partnerships along the whole supply chains (seed, production/processing, packaging, wholesale and retail). Thus it is possible that a powerful buyer does not force farmers to sell to it directly but it may induce such sales due to benefits that may come from other parties within the same network. For example, it is easier to arrange credit facilities with a credit provider if farmers sell solely to the powerful buyer who has connection with the credit provider. 


\subsection{Poultry}

The poultry market may be prone to monopsony conditions. The product concerned is broiler chicken. The powerful buyer is integrator which has presence in both upstream and downstream markets [Malaysian Competition Commission, (2014), p.9]. The integrators which are very few in Malaysia $(62.5 \%$ of the market was held by ten integrators [Malaysian Competition Commission, (2014), p.2]) operate both grandparent stock farms and parent stock farms (Yong, 2019). Through these farms the integrators sell chicks to farmers (Yong, 2019). The integrators also operate plants that process the animal feed that they sell to the farmers. The farmers will contract with an integrator where upon the expiration of a certain period, they will make available chicken which have to have the qualities specified by the integrator, and transported also according to standards set by the integrator before the chicken are processed by the same integrator (Yong, 2019). The integrator will process the chicken and sell them to distributors, wholesalers and retailers. If the standards are not followed, the farmers may be asked to compensate the integrator (Yong, 2019). The integrator contracts with a great number of farmers such that in terms of the quantity purchased, the integrator has a lot to bargain with the farmers. Farmers are also expected to invest because they may be required to comply with latest technology, standards and practices. For example, a few state governments now are making it compulsory for farmers to use closed chicken coops, a more expensive method than the open ones (Yong, 2019). Due to the high investment needed, it will be more difficult for the farmers to find alternative purchasers for their products.

\section{Malaysian competition legal framework}

Competition law has to apply to monopsony cases because the law protects competition in the market through rules on market structure and market conduct. Competition law is also supposed to remedy market imperfections though there can be exceptions with regard to natural monopoly. The comprehensive competition statute in Malaysia is the Competition Act 2010 (CA 2010). At the time of the writing of this article, the CA 2010 only has provisions on market conduct. There are no provisions regulating market structure, hence ex ante regulation of mergers involving monopsonist or powerful buyers is not covered by the CA 2010.

The CA 2010 prohibits two categories of anti-competitive conduct: anti-competitive agreement and abuse of dominant position. The types of conduct which are prohibited by the CA 2010 are elucidated in Table 1.

Table 1 shows that the prohibition of acquisition of supply by a single purchaser or a few powerful purchasers is not spelt out in either Section 4 or Section 10 of the CA 2010. However, both provisions may implicitly implicate such buyers. There is a need to differentiate between conduct that involves more than one powerful buyer (under the notion of anti-competitive agreement) and unilateral monopsony conduct (under the notion of abuse of dominant position). Since monopsony has always been equated to monopoly it is better to begin with the second category which is unilateral monopsony conduct. 
Table 1 Types of conduct prohibited by the Competition Act 2010

\begin{tabular}{|c|c|c|c|}
\hline \multicolumn{3}{|c|}{ Chapter 1 prohibition } & Chapter 2 prohibition \\
\hline \multicolumn{3}{|c|}{ Anti-competitive agreement (Section 4) } & $\begin{array}{c}\text { Abuse of dominant position } \\
\text { (Section 10) }\end{array}$ \\
\hline Level & Type & $\begin{array}{l}\text { By effect } \\
\text { or object }\end{array}$ & Type \\
\hline \multirow[t]{7}{*}{ Horizontal } & Price fixing & Object & $\begin{array}{l}\text { Unfair pricing/trading } \\
\text { conditions }\end{array}$ \\
\hline & $\begin{array}{c}\text { Sharing markets or source } \\
\text { supply }\end{array}$ & & $\begin{array}{l}\text { Limiting or controlling } \\
\text { production }\end{array}$ \\
\hline & Limiting or controlling prod & & Refusal to supply \\
\hline & Bid rigging & & $\begin{array}{l}\text { Market discrimination } \\
\text { (incl price discrimination) }\end{array}$ \\
\hline & Information sharing & Effect & Tying/bundling \\
\hline & Restrictions on advertisi & & Predatory behaviour \\
\hline & Standardisation agreeme & & Buying up scarce resources \\
\hline \multirow[t]{5}{*}{ Vertical } & Resale price maintenan & & Margin squeeze \\
\hline & Exclusive purchase agrees & & \\
\hline & $\begin{array}{l}\text { Exclusive distribution agre } \\
\text { covering a geographical }\end{array}$ & & \\
\hline & $\begin{array}{c}\text { Exclusive customer alloce } \\
\text { agreement }\end{array}$ & & \\
\hline & Up-front access paymer & & \\
\hline
\end{tabular}

Source: MyCC guidelines on chapter 1 prohibitions and MyCC guidelines on chapter 2 prohibitions

\subsection{Unilateral conduct of a powerful buyer}

The unilateral conduct of a powerful buyer, and even monopsonist will attract the application of the rules against abuse of dominant position in section of the 10 CA 2010 . The existence of monopsony power in a powerful buyer alone is not prohibited by the CA 2010. The monopsonist or the powerful buyer must first abuse its dominant position in the market. Section 10(2)(a) can be relevant as it involves the imposition of unfair pricing or other trading conditions by a dominant buyer. The fact that a monopsonist middleman imposes too low prices on farmers or fishermen, for example, can be considered an unfair pricing or trading condition. There can also be non-pricing unfair conduct. For example, the middleman may impose cuts whether quantitatively or qualitatively on the produce that producers seek to sell through it. The monopsonist or powerful buyer that makes purchases from farmers has a say in determining the quantity or quality of the products that can be accepted, but if the reductions are justified by lack of quality, it may be difficult to say that the conduct of the monopsonist and powerful buyer is abusive. Even if it is found to be so, the conduct can have reasonable commercial justification hence excluded from liability by virtue of Section 10(3). It can be trickier if the reason for the cuts or reductions is to 'stabilise' prices. This will be a challenge to the application of Section 10 of the CA 2010 to monopsony cases that involve powerful buyers. 
Monopsony can also be read from the sui generis type of abuse found in Section 10(2)(g) - buying up scarce resources. Buying up scarce resources is unique. It is not found in EU competition law, but it has its origin in South African competition law. Section $10(2)(\mathrm{g})$ provides:

\begin{abstract}
"Buying up a scarce supply of intermediate goods or resources required by a competitor, in circumstances where the enterprise in a dominant position does not have a reasonable commercial justification for buying up the intermediate goods or resources to meet its own needs."
\end{abstract}

The recourse to Section $10(2)(\mathrm{g})$ can prevent powerful buyers with a dominant position from buying supplies in large quantities at the expense other purchasers. However, the small sellers are not the direct beneficiary of this provision.

\title{
4.2 Conduct involving more than one buyer
}

Non-single firm conduct of powerful buyers can be equated to oligopsony. Again, oligopsony is not found in the CA 2010. Such conduct can either fall under anti-competitive agreements (Section 4) or abuse of collective dominance (Section 10).

Anti-competitive agreements can be horizontal, i.e., between the powerful buyers themselves or vertical, i.e., between a powerful buyer and small sellers. The prohibition arising from these agreements has two types: prohibition by object and prohibition by effect. Prohibition by object means if any of the type of agreement mentioned in the prohibiting provision is found to exist, an infringement finding can be made without the need to prove the effect of the conduct against competition in the market. Prohibition by object is covered by Section 4(2) of the CA 2010 which is a deeming provision. Prohibition by effect requires market effects of the agreement to be assessed.

Powerful buyers including middlemen can form 'buyer cartels' especially if they fix purchase prices against small sellers. Such horizontal agreements can have anti-competitive object as per Section 4(2)(a) of the CA 2010. That provision clearly provides that price fixing is not only with regards to selling price but also purchase price indicating the relevance of buyer power. Then, Section 4(2)(b) speaks about sharing sources of supply which means agreeing to buy only from certain suppliers (MyCC guidelines on chapter 1 prohibition, para. 3.27.2). Section 4(2)(b) is about sharing, not controlling supply. Controlling production is mentioned in Section 4(2)(c) and it includes agreeing on production quotas which normally has the same effect as setting a higher price (MyCC guidelines on chapter 1 prohibition, para. 3.27.3). In addressing the issue of joint purchasing agreements by powerful buyers, both Section 4(2)(b) and Section 4(2)(c) may need to be combined. Joint actions by powerful buyers may involve a decision on who is to purchase from who [Section 4(2)(b)] and another decision to purchase the whole or most of the goods produced by each farmer before the purchased goods are collected or accumulated, whether processed or not, and resold at a far higher price. However, an agreement between the powerful buyers must be proven to exist, something which can be a challenge to the MyCC.

This is evident in the wood sellers case (Malaysian Competition Commission, 2017). The case is a non-infringement decision by the MyCC relating to purchase of rubber wood small $\operatorname{logs}$ to be processed into wood fibres before they are tuned into a special type of fibreboard panels, used to manufacture furniture. The purchasers subject to investigation were two big companies who produced the panels. They allegedly had 
colluded to fix prices by lowering the prices of small logs sold by loggers who contracted with rubber small holders. In fact, the two companies were alleged to have attempted to recruit a few other companies into the price fixing pact. It was claimed that the alleged collusive arrangement by the two purchasing companies had resulted in oppression on the contracting loggers which also harmed the small holders. Unfortunately, no infringement was recorded due to lack of evidence.

Apart from anti-competitive agreements, non-single conduct of powerful buyers can be caught by prohibition under Section 10 by falling under the category of abuse of collective dominance. Rather than attaching dominance to one enterprise, the notion of dominance relates to few market players. This may be relevant to oligopoly or oligopsony where the enterprises exercise significant market power together. They must act similarly to exclude equally efficient competitors from the market. Collective dominance is rare, however. This will act as a constraint to the use of Section 10 as will be discussed below.

\subsection{Constraints within Malaysian competition legal framework}

The analysis of the CA 2010 shows some constraints in the act's role in addressing the problems faced by small sellers in their relationship with powerful buyers. This is despite the position that monopsony and buyer power have within the body of knowledge underlying competition law and policy. This paper will first go to the overall view of the regulatory framework in Malaysia. Then it will look at the particularities of the provisions of the CA 2010.

Regarding the overall view of the CA 2010, among the main constraints is the very nature of the 2010 Act which follows the EU model. The model separates between law that protects the process of competition and law that addresses unfair competition. The objective of the CA 2010 is the protection of the competitive process, not competitors. At the time of the writing of this paper, Malaysia is yet to have legislation that addresses unfair competition. Interestingly, the Malaysian fair trade practices policy that preceded the CA 2010 has reference to unfair competition but the reference was dropped from the CA 2010 (Rahman and Ahamat, 2016). This makes it difficult for the CA 2010 to address questions like the use of coercion unless they are clearly mentioned in the type of anti-competitive conduct prohibited by the CA 2010. One of them is imposition of unfair prices and other trading conditions as a type abusive conduct [under Section 10(2)(a)]. Coercion can be considered unfair but fairness is difficult to measure and where entry barriers are low (for example, if it is easy to find alternative sources including from overseas), unfair pricing can be hardly abusive.

Regarding the particular provisions of the CA 2010, the analysis of Sections 4 and 10 of the act shows that the terms such as monopsony, duopsony or oligopsony are not found in those provisions. While there are still rooms for manoeuvre indirectly against such conduct by powerful buyers especially if it harms small sellers, lack of direct provisions may make it difficult for MyCC to act.

There is difficulty caused by the existing substantive and procedural requirements that need to be satisfied before an infringement finding under Section 4 or Section 10 is made. With regards to Section 4 (on anti-competitive agreement), although the implementation of a buyer cartel can fall under the deeming provision [Section 4(2)], it must be shown that an agreement to fix prices by the buyers for example, exists. Even if 
the definition of agreement under the CA 2010 is broad enough to cover mere attendance in a decision making event [in the USA, the test used is unity of purpose, common design or understanding, or meeting of the minds (American Tobacco Co. v. United States, 328 U.S. 781, 810 (1946) [see Joshua and Jordan, (2004), p.655])] there must be evidence to such an effect. The MyCC decision in wood sellers shows that quite a high threshold of evidence is needed in order to prove such an agreement.

In wood sellers, the downward trend in prices was noted by the MyCC but no sufficient link with the alleged anti-competitive agreement was found as the low prices were rather due to factors associated with market forces including oversupply of materials and lower demand from purchasers. There were indications as to possibly implicating facts such as both purchasers have plants close to each other which may facilitate cartels. This also was not enough to prove price fixing agreement between them. This is despite 'concerted practice' being included as a mode of cartel under the CA 2010 but to prove concerted practice is even more difficult on top of proving the behaviour of cartel including price fixing, market sharing, and output limitation.

The facts in the wood sellers case showed that the two companies purchased $60 \%$ and $70 \%$ of the relevant raw materials in Malaysia. This may indicate market power hence Section 10 of the CA 2010 (which speaks about abuse of dominant position) could be relevant, but it was not pursued. The greatest concern with Section 10 is the task of the respective regulator to conduct market analysis in order to establish dominance. This is on top of the necessity to prove the existence of an abuse. Market shares alone are not enough to determine dominance. One has to look at other factors including entry barriers. There are also challenges to proving abuse in the event that an unfair element is alleged because, as said, competition regulators may be reluctant to hold dominant firms accountable if entry barriers are low. This is where the speciality of monopsony or buyer power coming from the demand side may require monopsony or buyer power to be treated differently. Market power threshold can be lower for monopsony than it is for monopoly (Stucke, 2013). Hence there should be a case for greater concerns if such market power is exercised by the buyer at the expense of micro or very small sellers.

In the same case (wood sellers), at least two different regions (Southern and Northern regions of Peninsula Malaysia) were identified in which the products were sold by the powerful buyers, but because the case was based on Section 4(2), defining of the relevant geographical market was not needed. However, the facts offered could explain a lot about potential monopsony, oligopsony or buyer power. There were facts about prices for the product concerned in those regions. The region with more sellers registered more competitive prices than the region with fewer sellers. Analysis of the price as well as the number sellers can offer a good indicator as to the impact of the duopsony. In order to do as such, investigation had to be done based on Section 10 of the CA 2010.

This will be challenging because some notions are not easy to be operationalised. For example, collective dominance which should be brought to the fore needs to be effectively interpreted. If such notions are not well explained by law or policy, they will add on to the complexity in the market analysis that has to be completed. If monopsony (or its non-single equivalences) is to be investigated, the differentiations between monopoly (or oligopoly) and monopsony (or oligopsony) have to be grappled so that the question about whether the conduct of powerful buyers is harmful or not, can be answered. 


\section{Lessons that may be learnt from Indonesia?}

The comprehensive competition legislation in Indonesia is the Law No. 5 of 1999 concerning the ban on monopolistic practices and unfair business competition (Law No. 5 of 1999). The Indonesian competition legislation creates three main categories of prohibition:

1 prohibited contracts

2 prohibited activities

3 dominant position.

Unlike the Malaysian Competition Act 2010, there is a specific provision in Indonesian competition law that addresses the issue of monopsony. Article 18 of Law No. 5 of 1999 prohibits business actors from controlling the acquisition of supplies or acting as sole buyer of goods or services in the relevant market which may potentially cause monopolistic practices and/or unfair business competition [Article 18(1) of Law No. 5 of 1999]. By virtue of Article 18(2) business actors or enterprises are deemed to control the acquisition of supplies or to be acting as sole buyer if they control more than $50 \%$ of the market share of a certain type of goods or services. This makes it easier to prove that a powerful buyer controls acquisition of supplies or acts as a sole buyer of goods or services in the relevant market. It must be noted that monopsony power is not sufficient to warrant an action under the Indonesian competition law because the use the power must lead to unfair competition.

The Indonesian competition authority (KPPU) itself was reported to be involved in measures that sought to remove powerful buyers from the supply chain in the rice sector (CNN Indonesia, 2017). The KPPU considered to conduct an investigation against a powerful company in the rice industry in Bekasi, Java, Indonesia (PT IBU). The company bought husks from farmers at IDR4,900 per kg to be milled and sold as rice at between IDR13,700 and 20,400 per kg (Media Indonesia, 2017). The price was higher than those charged by other purchasers indicating that it could be welfare-improving for the farmers but the KPPU also considered its impact on other smaller rice millers.

The settlement of this case did not end with a clear verdict that competition law has been violated. The prosecution rather relied on the Law No. 18 of 2012 regarding food, the criminal code and the Law No. 8 of 1999 regarding consumer protection (Indrawan, 2018). The law enforcement in this case (i.e., the police) had been tainted with claims of maladministration (Pelitasari, 2017; Ginanjar, 2017) as it failed to scrutinise the inaccurate public complaints and made inconsistent findings. It also led to the revocation of the Ministry of Trade Regulation Number 27/2017 on food reference price that set the retail price of rice at $\mathrm{Rp} 9.000$ for consumers of all types. Overall this case shows that the KPPU failed to proceed to investigate the violation of competition law, but approximately 1,700 employees were dismissed or terminated (Aziza, 2017). The main purpose of Law No. 5 of 1999 to promote the welfare of the people could be argued to be put to test. One very interesting fact is that PT IBU was a rice miller and since it bought directly from the farmers, it could be said to have benefited the market by cutting out the powerful buyers from the supply chain. PT IBU could be said to promote the welfare of farmers due to their high purchase prices but the law enforcement saw it from a different angle. PT IBU bought dried grain from farmers in Karawan and Bekasi at very good 
prices and the prices were considered harmful to milling entrepreneurs who could not buy from farmers for that price (Kuswandi, 2017).

In the case of seaweed production in East Sumba, East Nusa Tenggara [better known as the PT ASTIL case (Komisi Pengawas Persaingan Usaha, 2016), the KPPU found that the suspect (PT Algae Sumba Timur Lestari (PT ASTIL)] had infringed Law No. 5 of 1999 for engaging in the practice of monoposony [Komisi Pengawas Persaingan Usaha, (2016), pp.221-224]. Farmers who harvested seaweed had to contract and sell their product (dried seaweed) to the suspect subject to certain standards, terms and conditions. The KPPU decided that the suspect infringed Article 18 because it acted as the sole buyer of dried seaweed in the market of East Sumba.

The decision of the KPPU in PT ASTIL was criticised on the ground that the monopsony-related arrangement offered farmers better prices and benefited them by increasing the number of seaweed producers and brought them out of poverty (Sari, 2016). This argument was not fully accepted by the KPPU because the law should not only consider benefits to the powerful buyer or the farmers but also the effects on other business actors including the powerful buyer's competitors (Sari, 2016). The decision of the KPPU was finally overturned by the Indonesian Supreme Court (Supreme Court of Indonesia, 2017). The supreme court viewed that PT ASTIL was a natural monopoly and also alluded to the fact that the farmers were not compelled to sell their produce to the alleged monopsonist because farmers could sell elsewhere (Supreme Court of Indonesia, 2017).

Apart from the unilateral conduct of a single enterprise alone, powerful buyers could be implicated by the contracts or agreements that they entered into. In Indonesia, powerful buyers who make joint purchases of goods from farmers or fishermen could be implicated by Article 13 of Law No. 5 of 1999 which prohibits enterprises from making any contract with the intention to jointly control the purchase or acquisition of supplies in order to control prices of goods or services in the relevant market (oligopsony). The market share is important in proving oligopsony. For example, if the contracting enterprises had $75 \%$ of the market share, their conduct could be prone to joint control of purchase of supplies infringing the prohibition of oligopsony.

There have been cases in which powerful buyers in sectors where micro and small enterprises sold their products to powerful buyers were investigated by the KPPU. The cases involved purchase of iron ore by two companies (Komisi Pengawas Persaingan Usaha Republik Indonesia, 2006a) and the purchase of raw salt by seven producers of Komisi Pengawas Persaingan Usaha Republik Indonesia (2006b).

In these cases, the suspects were investigated for oligopsony but the KPPU found that they did not infringe Law No. 5 of 1999. In PT Garam, the KPPU found that the market structure for the purchase of raw salt in North Sumatra is oligopsonic but the purchasing power was not caused by the agreement between the purchasers [Komisi Pengawas Persaingan Usaha Republik Indonesia, (2006b), para. 3.10.2.5]. It was also found that there was no agreement with the purpose of collectively acquiring the purchase or supply of salt in North Sumatra and to control its prices there (Komisi Pengawas Persaingan Usaha Republik Indonesia, 2006, para. 3.10.2.5). In Perusahaan Daerah Aneka Usaha Manuntung Berseri and PT. Kuang Ye Indo International Mining Development monopsony, oligopsony and abuse of dominance were read together as the basis for investigating powerful buyers. This made the proving of a breach of competition law by a powerful buyer difficult. Interestingly, in Perusahaan Daerah Aneka Usaha 
Manuntung Berseri and PT. Kuang Ye Indo International Mining Development, rather than emphasising on deregulation which is the fundamental character of competition law, the KPPU turned to regulated licensing as a possible solution in promoting fair competition and the framework that ensures business certainties for foreign investors, local investors and traditional miners [Komisi Pengawas Persaingan Usaha Republik Indonesia, (2006a), paras. 4-5].

The Indonesian experience shows that to use competition law provision on monopsony against powerful buyers is not an easy task. In the PTIBU case, the act of the powerful buyer was argued to be beneficial to the farmers but was detrimental to the buyer's competitors. The same was argued in PT ASTIL. These cases show that when it comes to single act of powerful buyer, the Indonesian competition authority gives special consideration to the some direct but short run benefits of the exercise of monopsony or buyer power to the farmers and other small sellers. As regards non-single conduct, i.e., conduct by more than one powerful buyer, investigations were complicated by the difficulty of drawing a nexus between buyer power and agreement by powerful buyers.

\section{Conclusions}

The discussion above show that monopsony and buyer power can explain the effect of the conduct of powerful buyers on small sellers. However, the operationalisation of competition law to address the monopsony scenarios that exist in Malaysia is limited. The Malaysian competition law whose main legislation is the Competition Act 2010 does not have explicit reference to monopsony or oligopsony. The existing prohibitions of anti-competitive agreement and abuse of dominant position can be used against powerful buyers, but the enforcement of those prohibitions is constrained by not only the high thresholds of the general substantive and procedural requirements that apply to both seller power and buyer power, but also the ambiguities in the comparison between them.

The study on Indonesia shows that its competition law has provisions which explicitly mention monopsony and oligopsony. However, enforcement of those provisions has also been constrained by insufficient economic and legal evidentiary tools. Hence, positive findings of infringement or violation are hard to be made despite the existence of monopsonic or oligopsonic conditions in the market.

Consequently, the inclusion of monopsony, oligopsony or buyer power into competition legislation does not guarantee more effective action against the conduct of powerful buyers that harms small sellers. There is difficulty in proving anti-competitive conduct of the powerful buyers. Hence, the focus of the law should shift to the how the law deals with anti-competitive market structure, or to extraneous means including the law that protects micro, SMEs.

Indonesia has Law No. 20 of 2008 regarding micro, SMEs. Article 35(1) of the law that prohibits large enterprises from owning and/or controlling micro, small, and/or medium enterprise as their business partners in the implementation of partnership relationship. The contractual relationships between large enterprises and micro/small enterprises are regulated through principles such as core plasma.

Core plasma refers to a relationship between a large or medium enterprise which acts as core and a micro or small enterprises which acts as the plasmas of the former [Pakpahan, (2014), p.101]. With such a concept medium and large enterprises may be required by Article 27 of Law No. 20 of 2008 to help micro and small enterprises in 
providing them with among others production facilities, technical guidance and marketing of their production [Pakpahan, (2014), p.101]. The relationship between both must create mutual benefits. Like in molecular science, the core plasma concept ties a group of micro and small enterprises to a large enterprise in the smallest unit so that the core will work in symbiosis with its plasmas. Focusing on the last aspect of the assistance, i.e., marketing assistance, a powerful buyer which markets the products of a micro and small enterprise can be regulated by this law in ensuring that the purchases made will not harm the interests of the micro or small seller. The implementation of the core plasma concept against unethical powerful buyers will be an interesting thing to be observed.

The differences between Indonesia and Malaysia in terms of political, economic, social and legal landscapes need to be taken into account though. But it is possible that the difficulty of the law enforcement in addressing the problems faced by micro and small enterprises in the market persists in both countries. Therefore, future research can be undertaken to study the introduction of unfair competition law in Malaysia. The research should look at whether the unfair competition law can address the loopholes in the CA 2010 in relation to monopsony and buyer power. Research can also be conducted on monopsony and buyer power in services sector as the discussion in this paper focuses on the goods sector. Services sector are now being subject to critical studies especially where the digital economy and the digital market are involved. There is an issue whether market players such as digital platforms are buyers or mere middlemen. Monopsony and middlemen can be found in services sector including the digital market. Research can be done as to how the notion of monopsony interacts with the factors that make the digital market different from conventional market. For example, there are digital platforms and there can a question as to whether the platforms such as Uber are buyers from service providers or mere middlemen. This will have implication on the possible extension of principles of monopsony to new cases.

\section{Acknowledgements}

This paper is funded via a research grant entitled 'Regulatory and institutional export barriers framework for agribusiness SMEs in Malaysia' (FRGS/1/2017/SSI10/ UKM/02/2), awarded by the Ministry of Higher Education of Malaysia.

\section{References}

Antaranews (2017) Kepala staf TNI AD ajak perangi tengkulak (Head of Staff of Indonesian Armed Forces Calls for Combating Powerful Buyers) [online] https://www.antaranews.com/berita/ 622442/kepala-staf-tni-ad-ajak-perangi-tengkulak (accessed 2 December 2017).

Aziza, K.S. (2017) Kompas.com [online] http://ekonomi.kompas.com/read/2017/12/20/184700326/ hentikan-bisnis-beras-pt-tiga-pilar-phk-1.700-karyawan (accessed 8 February 2018).

Carstensen, P.C. (2004) 'Buyer power and merger analysis - the need for different metrics', in Proceedings of the Workshop on Merger Enforcement Held by the Antitrust Division and the Federal Trade Commission, Vol. 17.

ChePa, N., Yusoff, N. and Ahmad, N. (2016) 'Determinants for grading Malaysian rice', in AIP Conference Proceedings, AIP Publishing, Vol. 1761, No. 1, p.020035. 
CNN Indonesia (2017) KPPU Dorong Pangkas Rantai Distribusi Beras (KPPU Pushes to Cut Rice Distribution Chain) [online] https://www.cnnindonesia.com/ekonomi/20170729141142-92231166/kppu-dorong-pangkas-rantai-distribusi-beras (accessed 5 December 2017).

Enete, A.A. (2009) 'Middlemen and smallholder farmers in cassava marketing in Africa'. Tropicultura, Vol. 27, No. 1, pp.40-44.

Federal Trade Commission and US Department of Justice (2000) Antitrust Guidelines for Collaborations among Competitors [online] https://www.ftc.gov/sites/default/ files/documents/public_events/joint-venture-hearings-antitrust-guidelines-collaborationamong-competitors/ftcdojguidelines-2.pdf (accessed 15 August 2019).

Ganesh, A.R. (2010) 'The right to food and buyer power', German L.J., Vol. 11, p.1190.

Ginanjar, D. (2017) Jawapos.com [online] https://www.jawapos.com/read/2017/07/29/147407/ ombudsman-ungkap-tiga-kejanggalan-kasus-beras-maknyuss (accessed 8 February 2018).

Hayami, Y., Kawagoe, T. and Morooka, Y. (1988) 'Middlemen and peasants: the structure of the Indonesian soybean market', The Developing Economies, Vol. 26, No. 1, p.1.

Indrawan, A.F. (2018) Detik.com [online] https://news.detik.com/berita/d-3818351/kasus-berasberlabel-palsu-dirut-pt-ibu-dituntut-2-tahun-bui (accessed 8 February 2018).

Ishak, S., Hussain, M.Y., Che Omar, A.R., Awang, A.H. and Lyndon, N. (2017) 'Meneroka Refleksi Simpati Rasional Orang Tengah dalam Rantaian Pengeluaran Kelapa Sawit Pekebun Kecil', Akademika, Vol. 87, No. 2, pp.45-61.

Jacobson, J.M. and Dorman, G.J. (1992) 'Monopsony revisited: a comment on Blair \& Harrison', The Antitrust Bulletin, Vol. 37, No. 1, pp.151-169.

Joshua, J.M. and Jordan, S. (2004) 'Combinations, concerted practices and cartels: adopting the conspiracy in European community competition law', Northwestern Journal of International Law and Business, Vol. 24, No. 3, pp.647-682.

Komisi Pengawas Persaingan Usaha Republik Indonesia (2006a) Perusahaan Daerah Aneka Usaha Manuntung Berseri \& PT. Kuang Ye Indo International Mining Development, 12/KPPU$\mathrm{L} / 2005$.

Komisi Pengawas Persaingan Usaha Republik Indonesia (2006b) PT Garam \& Others, 10/KPPU$\mathrm{L} / 2005$.

Komisi Pengawas Persaingan Usaha (2016) Perdagangan Rumput Laut Produksi Sumba Timur, Nusa Tenggara Timur (PT ASTIL), 21/KPPU-L/2015.

Kuswandi (2017) Kompas.com [online] https://www.jawapos.com/read/2017/07/29/147406/saiddidu-pemerintah-lakukan-pemahaman-salah-soal-hpp (accessed 8 February 2018).

Landa, J.T. (2016) Economic Success of Chinese Merchants in Southeast Asia: Identity, Ethnic Cooperation and Conflict, Springer, Toronto.

Malaysian Competition Commission (2014) Review of Domestic Broiler Market: Final Report, Kuala Lumpur.

Malaysian Competition Commission (2017) Finding of Non-Infringement Under Section 39 of the Competition Act 2010 of Dongwha Fibreboard Sdn. Bhd. and Evergreen Fibreboard Bhd., $\operatorname{MyCC}(E D) 700-1 / 2 / 6 / 2015$.

Media Indonesia (2017) KPPU Dalami Kemungkinan Praktik Monopoli oleh PT. IBU (KPPU to Go Deep into the Possibility of Monopoly Practices [online] http://mediaindonesia.com/news/ $\mathrm{read} / 114366 / \mathrm{kppu}$-dalami-kemungkinan-praktik-monopoli-oleh-pt-ibu/2017-07-24 (accessed 17 December 2017).

Mitra, S., Mookherjee, D., Torero, M. and Visaria, S. (2018) 'Asymmetric information and middleman margins: an experiment with Indian potato farmers', Review of Economics and Statistics, Vol. 100, No. 1, pp.1-13.

Noll, R.G. (2004) 'Buyer power and economic policy', Antitrust L.J., Vol. 72, No. 2, p.589.

OECD (2008) 'Monopsony and buyer power', OECD Policy Round Tables.

Pakpahan, A.K. (2014) The Development of Business Clusters in Indonesia: the Cases of Cibaduyut and Plered, West Java, Nomos, Baden-Baden. 
Pelitasari, L. (2017) Ombudsman Ungkap Tiga Kejanggalan Kasus Beras Maknyuss, Edited by Dhimas Ginanjar.

Rahman, N.A. and Ahamat, H. (2016) Competition Law in Malaysia, Sweet \& Maxwell, Subang Jaya.

Rakyat Pos (2015) Tengkulak Penyebab Petani Miskin [online] http://www.rakyatpos.com/ tengkulak-penyebab-petani-miskin.html/ (accessed 20 November 2017).

Rashid, H.R.A. (2018) '30 percent of Bernas monopoly to be opened to other players', New Straits Times [online] https://www.nst.com.my/news/nation/2018/10/422059/30-percent-bernasmonopoly-be-opened-other-players (accessed 14 June 2019).

Ray, D.M. (1994) 'The role of risk-taking in Singapore', Journal of Business Venturing, Vol. 9, No. 2, pp.157-177.

Sari, D.P. (2016) Dugaan Monopsoni: PT ASTIL Tantang KPPU Buktikan Kerugian Petani Rumput Laut (Monopsony Allegation: PT ASTIL Challenges KPPU to Prove Seaweed Farmers Suffer Losses) [online] http://kabar24.bisnis.com/read/20160314/16/527666/dugaanmonopsoni-pt-atsil-tantang-kppu-buktikan-kerugian-petani-rumput-laut- $\quad$ (accessed 23 December 2017).

SME Corp Malaysia (2013) Guideline for New SME Definition [online] http://www.smecorp.gov.my/images/pdf/Guideline_New_SME_Definition_updated.pdf (accessed 15 August 2019).

Stucke, M.E. (2013) 'Looking at the monopsony in the mirror', Emory Law Journal, Vol. 62, p.1509.

Supreme Court of Indonesia (2017) PT Algae Sumba Timur Lestari \& Ir. M. Maxon M. Pekuwali v $K P P U, 18 /$ Pdt.G.Bth/2016/PN.Wgp.

Suzuki, A. and Sexton, R.J. (2005) Transportation Cost and Market Power of Middlemen: A Spatial Analysis of Agricultural Commodity Markets in Developing Countries (No. 378-2016-21453) [online] https://ageconsearch.umn.edu/record/19329/ (accessed 7 October 2019).

Utusan Malaysia (2014) Jihad perangi orang tengah (Jihad Against Powerful Buyers) [online] http://ww1.utusan.com.my/utusan/Dalam_Negeri/20140210/dn_01/Jihad-perangi-orangtengah (accessed 21 November 2017).

Vengedasalam, D., Harris, M. and Gordon MacAulay, T. (2011) Malaysian Rice Trade and Government Interventions [online] https://ageconsearch.umn.edu/record/100726/ (accessed 1 May 2019)

Wong, L.C.Y., Emrus, S.A., Bashir, B.M. and Tey, J.Y.S. (2010) 'Malaysian padi and rice industry: applications of supply chain management approach', in Proceedings of the National Rice Conference Theme: Strengthening Food Security through Sustainable Rice Production, pp.28-30.

Yong, H.N.A. (2008) 'Supply chain model for rice in Malaysia - basics and challenges', in ECER Regional Conference.

Yong, S.S. (2019) Perundangan Monopsoni dan Kuasa Pembeli dalam Sektor Poultri di Malaysia, Unpublished Law Undergraduate thesis, Universiti Kebangsaan Malaysia. 